Moszyńska A., Instytucjonalne ramy ochrony konkurencji w Polsce - historia i wspótczesnośc, „Ekonomia i Prawo”, Polszakiewicz B., Boehlke J. (red.), Tom XII, nr 2/2013, ss. 245-259. DOI: $\underline{\text { http://dx.doi.org/10.12775/EiP.2013.019 }}$

\title{
INSTYTUCJONALNE RAMY OCHRONY KONKURENCJI W POLSCE - HISTORIA I WSPÓŁCZESNOŚĆ
}

\section{STRESZCZENIE}

Artykuł koncentruje się na przedstawieniu genezy polskiego prawa antykartelowego i działalności pierwszych organów antymonopolowych: Sądu Kartelowego i Ministra Przemysłu i Handlu. Dalsze uwagi poświęcone zostały zagadnieniu współczesnego modelu ochrony konkurencji w Polsce. Szczególny nacisk został położony na status organu antymonopolowego i kwestię jego politycznej neutralności. Pomimo wprowadzenia w 2000 r. wyboru Prezesa UOKiK w drodze konkursu i wyposażenia go w ustawowe gwarancje niezależności, siedem lat później powrócono do wcześniejszych rozwiązań. Obecna regulacja nie pozwala na całkowite oderwanie organu antymonopolowego od bieżącej polityki rządu. Tylko zaś pełna niezależność zabezpieczyłaby interesy ogółu, pozwoliłaby na urzeczywistnienie ustroju opartego na konkurencji i nie pozostawiłaby miejsca dla politycznych ingerencji kolejnych ekip rządowych. Utrzymanie tak ważkiej kwestii w nurcie bieżącej polityki stanowi zbyt duże ryzyko i - w świetle teorii i praktyki konkurencji - nie ma żadnego uzasadnienia.

Słowa kluczowe: ochrona konkurencji, Sąd Kartelowy, UOKiK

Klasyfikacja JEL: K21, N24

* Anna Moszyńska, Uniwersytet Mikołaja Kopernika, Wydział Prawa i Administracji, Katedra Historii Państwa i Prawa Polskiego, e-mail: annaf@law.umk.pl. 


\title{
INSTITUTIONAL FRAMEWORK OF COMPETITION PROTECTION IN POLAND - HISTORY AND PRESENT
}

\author{
SUMMARY
}

This article focuses on the presentation of the origins of Polish antitrust law and its first authorities: Cartel Court and the Minister of Industry and Trade. Further attention has been devoted to the issue of the contemporary model of competition in Poland. Particular emphasis has been placed on the status of the antitrust authority and the question of its political neutrality. Despite the introduction of the President of the OCCP election by open competition and providing its guarantees of independence in 2000, seven years later legislator returned to the previous solutions. The present regulation does not allow to a complete separation of antitrust office from the current government's policy. Only full independence would secure interests of all, allow for the realization of the system based on competition and would leave no room for political interference by successive Polish governments. Leaving such weighty issues in the mainstream of the current policy is too much risk and for which - in the light of the theory and practice of competition - there is no justification.

Keywords: competition protection, Cartel Court, OCCP

JEL Classification: K21, N24

\section{WSTĘP}

Ramy ustroju gospodarczego w Polsce, zgodnie z wyraźnym brzmieniem konstytucji, określa koncepcja społecznej gospodarki rynkowej ${ }^{1}$. Koncepcja ta czerpie z osiągnięć naukowych doktryny ordoliberalizmu. Według przedstawicieli tego nurtu, ochrona ustroju opartego na konkurencji powinna być powierzona niezależnemu państwowemu urzędowi kontroli podległemu jedynie ustawie $^{2}$. Inne rozwiązania kwestii obecności karteli i monopoli w życiu gospodarczym - poprzez upaństwowienie monopoli czy kontrolę wewnętrzną przez pracowników zmonopolizowanych przedsiębiorstw - nie zdały egzaminu. Aby jednak system ochrony konkurencji mógł być efektywny, centralny organ powołany w tym celu musi być niezależny od rządu i od parlamentu. Tyl-

${ }^{1}$ Konstytucja Rzeczypospolitej Polskiej z dnia 2 kwietnia 1997 r., Dz. U. Nr 78, poz. 483, art. 20.

${ }^{2}$ W. Eucken, Podstawy polityki gospodarczej, Wydawnictwo Poznańskie, Poznań 2005, s. 334; H. Grossekettler, Franz Böhm (1895-1977), [w:] J.G. Backhaus (red.), The Elgar Companion to Law and Economics, Edward Elgar, Cheltenham, Northampton 2005, s. 494-495. 
ko takie ukształtowanie urzędu antymonopolowego pozwoli odseparować go od wpływów grup interesów i rządu ${ }^{3}$. Zadań ochrony konkurencji nie można więc powierzyć departamentowi ministerstwa odpowiedzialnego za gospodarkę, który w znacznie większym stopniu byłby podatny na naciski.

Taki urząd według wizji W. Euckena, głównego teoretyka ordoliberalizmu, powinien być wyłącznie odpowiedzialny za wszystkie sprawy związane $\mathrm{z}$ nadzorem nad monopolami ${ }^{4}$. W pejzażu nowoczesnego państwa powinien zajmować centralną pozycję, w przeciwnym wypadku zagrożona będzie realizacja ustroju opartego na konkurencji, jak i postulatu państwa prawa. W jego ocenie „urząd antymonopolowy jest tak samo potrzebny jak sąd najwyższy" Porównanie do najwyższego sądu w państwie egzemplifikuje niezbędną cechę urzędu - niezależność.

Polski system ochrony konkurencji nie ma zbyt długiej tradycji. W okresie międzywojennym jego ramy instytucjonalne tworzyła ustawa antykartelowa z 1933 r. Ponowne tworzenie systemu antymonopolowego nastąpiło dopiero w 1987 r., a transformacja ustrojowa przyniosła jego gruntowną przebudowę po $1990 \mathrm{r}$.

Te kilkadziesiąt lat historii polskiego systemu ochrony konkurencji zachęca do podjęcia rozważań o jego charakterze. Warto zastanowić się, na ile wprowadzone w poszczególnych okresach regulacje prawne realizowały postulaty doktryny ordoliberalnej, w szczególności dotyczące niezależności organu antymonopolowego. Celem niniejszego artykułu jest próba odpowiedzi na pytanie, czy systemy ochrony antymonopolowej w Polsce stanowiły elementy świadomej długookresowej polityki ładu gospodarczego, czy też mieściły się w nurcie polityki rządu i realizowały jego doraźne cele. Opracowanie kończy podsumowanie ewolucji polskiego systemu ochrony konkurencji oraz wnioski de lege ferenda.

\section{SYSTEM OCHRONY KONKURENCJI W II RP}

W okresie międzywojennym system ochrony konkurencji przeszedł bardzo dużą ewolucję. Czasy II RP charakteryzuje stopniowe zaostrzanie polityki władz w stosunku do karteli - od współpracy ze światem wielkiego kapitału, a nawet wspierania działalności kartelowej, poprzez wprowadzanie ograniczeń

${ }_{3}$ M. Błachucki, System postępowania antymonopolowego w sprawach kontroli koncentracji przedsiębiorców, UOKiK, Warszawa 2012, s. 96.

${ }^{4}$ W. Eucken, op. cit., s. 334.

${ }^{5}$ Ibidem. 
dla monopoli, aż do całkowitego podporządkowania karteli państwu. Możemy określić wyraźne cenzury czasowe i wskazać 3 momenty zwrotne w rozwoju międzywojennego systemu antymonopolowego: 1933, 1935, 19396. Lata te to daty uchwalania nowych regulacji antykartelowych. Zmianom w polityce rządu towarzyszyła bowiem odpowiednia zmiana przepisów prawnych.

Dyskusję o potrzebie budowy systemu ochrony konkurencji podjęto dopiero w 1925 r. Wcześniej kwestia koncentracji nie znajdowała się w polu zainteresowania rządu, co wynikało $\mathrm{z}$ powolnego tempa monopolizacji w pierwszych latach po odzyskaniu niepodległości ${ }^{7}$. Sytuacja gospodarcza nie sprzyjała bowiem koncentracji przedsiębiorców ${ }^{8}$.

Recesja, która nastąpiła w sierpniu 1925 r., zaostrzyła walkę o rynek i dała impuls do gwałtownego przyspieszenia procesów kartelizacji ${ }^{9}$. Jedną z przyczyn załamania koniunktury była polsko-niemiecka wojna celna ${ }^{10}$. Konieczne stało się zdobycie nowych rynków zbytu, a cel ten o wiele łatwiej było osiągnąć zrzeszonym przedsiębiorstwom niż pojedynczym zakładom. W takiej sytuacji rząd podejmował działania wspomagające polski przemysł, także ten skartelizowany. Na poparcie mogły liczyć przede wszystkim porozumienia proeksportowe.

Inną przyczyną prokartelowej polityki rządu był sojusz sanacji, która doszła do władzy w wyniku przewrotu majowego w 1926 r., ze światem wielkiego kapitału. Utrzymanie się nowych ekip przy władzy wymagało poparcia finansowego, które mogły zapewnić i zapewniały koncerny ${ }^{11}$. Przed wydaniem ustawy kartelowej w 1933 r. istniały przepisy umożliwiające władzom wpływanie na działalność monopoli, jednak w praktyce nie były one wykorzystywane przeciwko zrzeszeniom przedsiębiorców ${ }^{12}$. Wprowadzane w następnych

${ }^{6}$ Ewolucję polityki gospodarczej rządu w stosunku do karteli przedstawia Z. Landau (Rozwój ustawodawstwa kartelowego w Polsce międzywojennej na tle polityki kartelowej rządu, „Kwartalnik Historyczny”, z. 1/1972, s. 69-86). Wyróżnia on 3 okresy w polityce kartelowej państwa: 1918-1924, 1925-1933, 1933-1939. Podobny podział stosuje A. Podolska-Meducka, Polskie ustawodawstwo kartelowe w latach 1918-1939, Wydawnictwo Sejmowe, Warszawa 2003.

7 Z. Landau, op. cit., s. 70 . W 1918 r. funkcjonowało tylko 7 karteli, a w 1923 r. ich liczba wzrosła zaledwie do 31 (A. Podolska-Meducka, Polskie ustawodawstwo..., op. cit., s. 33).

${ }^{8}$ Ibidem.

${ }^{9}$ Liczba porozumień rosła z roku na rok w o wiele szybszym tempie - w 1927 r. działało już 64 karteli, a w 1929 r. - 100 (A. Podolska-Meducka, Polskie ustawodawstwo, s. 53).

${ }^{10}$ M. Krajewski, Historia gospodarcza Polski do 1989 roku. Zarys problematyki, Wyższa Szkoła Humanistyczno-Ekonomiczna, Włocławek 2000, s. 312.

${ }^{11}$ Konkretne przykłady wsparcia finansowego rządu ze strony syndykatów gospodarczych podaje Z. Landau, op. cit., s. 71.

12 Obowiązujące w poszczególnych dzielnicach państwa przepisy zaborcze nie zawierały odrębnych norm antymonopolowych, umożliwiały jednak m.in. unieważnienie umowy kartelowej 
latach regulacje wyposażały władze w dalsze instrumenty prawne, które mogły zostać użyte $\mathrm{w}$ podobnym celu $^{13}-$ mogły, lecz $\mathrm{w}$ praktyce nigdy nie zostały skierowane przeciwko kartelom ${ }^{14}$.

W opisywanym okresie $\mathrm{w}$ kołach rządowych rozpoczęto też prace nad ustawą dotyczącą nadzoru państwowego nad kartelami ${ }^{15}$. Ukończony w $1928 \mathrm{r}$. projekt nie spotkał się jednak $\mathrm{z}$ większym zainteresowaniem w rządzie, który wręcz spowolnił dalsze prace nad nim.

Należy podkreślić, iż zjawisko koncentracji przedsiębiorców nie było wówczas odbierane jednoznacznie negatywnie. Przedsiębiorstwa państwowe uczestniczyły w kartelach, co więcej kartele - i to w sposób przymusowy - były tworzone przez państwo ${ }^{16}$. Postrzegano je jako skuteczne narzędzie polityki ekonomicznej, za pomocą którego można było zapobiec dezorganizacji rynku wewnętrznego ${ }^{17}$. Poprzez wyznaczenie wolumenu produkcji w danym okresie i przydziały kontyngentu pomiędzy poszczególne zakłady stowarzyszone dążono do zlikwidowania wyniszczającej walki pomiędzy przedsiębiorcami. Tak skonstruowane zrzeszenia przymusowe nie miały likwidować konkurencji, lecz zmieniać jej charakter ${ }^{18}$. Liczono, iż dzięki nim gospodarka przezwycięży kryzys, osiągnie stan równowagi oraz nastąpi intensyfikacja procesu uprzemysłowienia.

Zmiana polityki rządu nastąpiła dopiero na skutek niezadowolenia społecznego wywołanego kryzysem, który obnażył negatywne skutki kartelizacji przedsiębiorstw. Najbardziej palącym problemem stała się kwestia wysokich cen - pomimo obniżania kosztów produkcji przez skartelizowane podmioty, ceny utrzymywały się na zawyżonym poziomie. Kartele ograniczały produk-

jako sprzecznej z dobrymi obyczajami (zob. więcej: Z. Landau, op. cit., s. 72). Wydana w 1920 r. ustawa o zwalczaniu lichwy wojennej pozwalała stosować bardzo surowe kary wobec uczestników zmowy lub związku mających na celu m.in. wprowadzenie lub utrzymanie zwyżki cen. Za przestępstwo to groziła kara ciężkiego więzienia od 1 roku do 15 lat i grzywna do 2 milionów marek; możliwe było nawet orzeczenie kary śmierci w przypadku, gdy sprawca wyrządził lub zamierzał wyrządzić ciężką szkodę interesom publicznym (Ustawa z dnia 2 lipca $1920 \mathrm{r}$. o zwalczaniu lichwy wojennej, Dz. U. Nr 67, poz. 449, art. 24 ust. 5 w zw. z art. 19).

${ }_{13}$ Wymienić tu można Rozporzadzenie Prezydenta Rzeczypospolitej z dnia 31 sierpnia $1926 \mathrm{r}$. o zabezpieczeniu podaży przedmiotów powszedniego użytku, Dz. U. Nr 91, poz. 527.

${ }^{14}$ Z. Landau, op. cit., s. 73

15 Odnośnie do projektów legislacyjnych w tym zakresie zob.: A. Podolska-Meducka, Projekty ustawy kartelowej w Polsce międzywojennej, „Czasopismo Prawno-Historyczne”, t. LIV, z. 2/2002, s. 215-257.

${ }_{16}$ Zob. więcej: M. Łapa, Przymusowa kartelizacja przemystu II Rzeczypospolitej w latach 192533, „Acta Universitatis Lodziensis. Folie Historiae”, nr 60/1997.

17 A. Podolska, Polska ustawa kartelowa w II Rzeczypospolitej, „Czasopismo Prawno-Historyczne”, t. LII, z. 1-2/2000, s. 153.

18 A. Podolska, Polska ustawa..., op. cit., s. 154. 
cję, zamykały liczne fabryki, co doprowadziło do wzrostu bezrobocia, które w szczytowym momencie osiągnęło poziom $43 \%{ }^{19}$. Wobec niezadowolenia społecznego nadzór nad kartelami stał się kwestią polityczną ${ }^{20}$. Uchwalenie ustawy antymonopolowej pozwalało rządowi zrealizować dwa cele. Po pierwsze, stwarzało pozory walki z kryzysem i odciągało uwagę społeczeństwa od niepowodzeń władz na gruncie gospodarczym. Po drugie, umożliwiło obozowi rządzącemu, zgodnie $\mathrm{z}$ głoszonymi przez sanację hasłami etatyzmu, wywieranie coraz większego wpływu na życie gospodarcze ${ }^{21}$. Dlatego też w szybkim tempie wprowadzono w życie projekt, który od 1928 r. leżał na półce.

Uchwalona w dniu 28 marca 1933 r. ustawa ${ }^{22}$ wprowadzała dwie główne instytucje systemu ochrony konkurencji: Sąd Kartelowy i rejestr karteli. Każda umowa kartelowa podlegała obowiązkowi zgłoszenia do rejestru prowadzonego przez Ministra Przemysłu i Handlu (MPiH). Rejestr ten był jawny ${ }^{23}$. Jeśli treść lub sposób wykonywania umowy kartelowej zagrażał dobru publicznemu, Sąd Kartelowy mógł orzec o jej rozwiązaniu ${ }^{24}$. Przesłanka zagrożenia dobra publicznego występowała w szczególności, gdy uregulowanie w umowie produkcji, zbytu lub ograniczanie swobody wymiany dóbr powodowało skutki gospodarczo wadliwe, bądź jeśli ceny zostały podwyższone lub utrzymane na poziomie gospodarczo nieusprawiedliwionym ${ }^{25}$. Sąd rozstrzygał też odwołania od orzeczenia ${ }^{26}$ Ministra Przemysłu i Handlu o nałożeniu kary grzywny za naruszenie obowiązku zgłoszenia kartelu do rejestru ${ }^{27}$.

Jedynym podmiotem, który mógł inicjować postępowanie przed Sądem Kartelowym, był Minister Przemysłu i Handlu. Żaden podmiot samorządowy, pojedynczy przedsiębiorcy czy ich stowarzyszenia, obywatele lub organizacje społeczne nie miały takiego uprawnienia. Pozostawała im długa i żmud-

${ }_{19}$ M. Krajewski, Historia gospodarcza..., op. cit., s. 323.

${ }^{20}$ Z. Landau, op. cit., s. 76. Por. także: L.P., Kartele a kryzys, „Kurjer Lubelski” z 5 lutego 1932 r., r. X, nr 36/1932, s. 1 . Autor wyraża w nim bardzo rozpowszechniony pogląd, iż „kartele, pasożytujące na całem społeczeństwie, wciągają nas w jeszcze głębszy kryzys i przeciąają go sztucznie, stając na przeszkodzie zdrowym tendencjom przebudowy życia gospodarczego".

${ }^{21}$ Por. W. Grabski, O wtasnych sitach. Zbiór artykutów na czasie, Gebethner i Wolff, Warszawa-Kraków-Lublin-Łódź-Paryż-Wilno-Zakopane 1926, s. 15.

22 Ustawa z 28 marca 1933 r. o kartelach, Dz. U. Nr 31, poz. 270.

23 Art. 3 ust. 3 stanowil, że „rejestr może każdy przeglądać”.

${ }^{24}$ Ustawa przyznawała sądowi też inne uprawnienia, m.in. upoważnienie uczestników kartelu do wystąpienia z niego, bez niekorzystnych dla nich skutków prawnych.

25 Art. 4 ust. 1 ustawy kartelowej.

${ }^{26} \mathrm{~W}$ świetle ustawy kartelowej minister wydał w tych sprawach nie decyzje lecz „orzeczenia” (art. 10 ust. 4); ustawa stwierdzała też, że „orzecznictwo należy Ministra Przemysłu i Handlu” (art. 10 ust. 2).

27 Art. 10 ust. 4 ustawy kartelowej. 
na walka przed powszechnym sądem cywilnym polegająca np. na wykazaniu konkretnej szkody wyrządzonej działalnością kartelu. Udowodnienie przesłanek takiej odpowiedzialności było jednak bardzo trudne.

Sąd Kartelowy działał przy Sądzie Najwyższym, stanowił jednak sąd specjalny. Rozwiązanie przyjęte w ustawie stanowiło kompromis, gdyż według jej pierwotnego projektu, sąd ten miał znajdować się przy Ministerstwie Przemysłu i Handlu ${ }^{28}$.

O tym, które kartele zagrażały dobru publicznemu, decydował Minister Przemysłu i Handlu. Ocenę tę weryfikował Sąd Kartelowy, jednakże ścisłe ograniczenie kognicji sądu wnioskiem ministra powodowało, że nie mógł on interweniować w przypadkach szkodliwych działań kartelu, w stosunku do którego minister nie wniósł wniosku. Spełnienie przez umowę kartelową przesłanki zagrożenia dobra publicznego nie oznaczało, że w każdym wypadku umowa taka zostanie rozwiązana, a jedynie wówczas, gdy było to zgodne z polityką rządu. Najlepiej świadczy o tym dobór kartelu, który miał stać się ofiarą pierwszego, przykładowego procesu przed Sądem Kartelowym ${ }^{29}$. Wskazuje też na to znikoma liczba spraw przedstawionych do rozstrzygnięcia Sądowi Kartelowemu ${ }^{30}$.

Pierwszy polski system ochrony konkurencji opierał się na modelu sądo$w_{y m}{ }^{31}$. W nauce wyróżnia się ponadto model administracyjny. W obu modelach występuje zarówno organ administracji, jak i czynnik sądowy. W modelu sądowym organ administracyjny najczęściej jedynie inicjuje postępowanie przed sądem, prowadzi postępowanie przygotowawcze i zbiera dowody, jednak podjęcie ostatecznego rozstrzygnięcia należy do sądu. Oprócz organu administracji postępowanie przed sądem mogą wszczynać także inne podmioty: konkurenci kartelu, a nawet konsumenci ${ }^{32}$. Model ten wywodzi się z krajów opartych na tradycji common law (USA, Australia), na kontynencie europejskim zaś występuje w Austrii.

28 Z. Landau, op. cit., s. 79.

29 Szczegółowo motywy wyboru kartelu cementowego opisuje Z. Landau, Rozwiązanie kartelu cementowego w Polsce w 1933 r., „Studia Historyczne”, z. 1/1972, s. 86; zob. również A. Podolska-Meducka, Sąd Kartelowy w Polsce i jego orzecznictwo w latach 1933-1935, „Czasopismo Prawno-Historyczne”, t. LIII, z. 2/2001, s. 96-97 i podana tam literatura (przypis 41).

${ }^{30}$ Do 1935 r. rozpatrywał on zaledwie 3 sprawy przedstawione przez ministra, z czego jedna dotyczyła wyplątania przedsiębiorstwa państwowego z niekorzystnie przez nie zawartej umowy kartelowej (dokładny opis okoliczności tej sprawy podaje A. Podolska-Meducka, Sad Kartelowy..., op. cit., s. 104-116). W każdej z tych spraw kartele przegrały spór z ministrem.

${ }^{31}$ Nie była to czysta postać tego modelu, gdyż jak wyżej wspomniano „orzecznictwo” w sprawach o naruszenie przepisów o zgłoszeniu do rejestru karteli należało do Ministra Przemysłu i Handlu, a Sąd Kartelowy rozstrzygał jedynie odwołania od orzeczeń ministra.

${ }^{32}$ M. Błachucki, System postepowania..., op. cit., s. 53. 
W modelu administracyjnym decyzje w zakresie prawa antymonopolowego podejmują organy administracji, sądy zaś kontrolują ich rozstrzygnięcia, w myśl konstytucyjnej zasady sądowej kontroli administracji. System ten jest charakterystyczny dla krajów Europy kontynentalnej ${ }^{33}$.

Sąd Kartelowy jedynie przez dwa lata miał możliwość orzekania w sprawach o rozwiązanie porozumień kartelowych. W 1935 r. wprowadzono daleko idącą nowelizację ustawy kartelowej ${ }^{34}$ - kompetencje sądu przekazano Ministrowi Przemysłu i Handlu. Sąd mógł od tej pory jedynie rozpoznawać środki odwoławcze od orzeczeń ministra. Możliwość wniesienia takiego odwołania została jednak skutecznie ograniczona zagrożeniem poniesienia wysokich kosztów w przypadku przegrania sprawy przez kartel ${ }^{35}$. W 1935 r., pomimo rozwiązania przez ministra kilkudziesięciu umów kartelowych, wniesiono zaledwie cztery odwołania od jego orzeczeń - po oddaleniu przez sąd pierwszego odwołania, pozostałe cofnięto ${ }^{36}$. W 1936 r. nie wniesiono już żadnych odwołań od orzeczeń ministra ${ }^{37}$.

Nowelizacja ustawy kartelowej z 1935 r. spowodowała w istocie zmianę modelu ochrony konkurencji z sądowego na administracyjny. Centralnym podmiotem odpowiedzialnym za nadzór nad kartelami stał się Minister Przemysłu i Handlu. Stanowiło to zaprzeczenie idei niezależnego od rządu organu antymonopolowego - minister nie tylko był zależny od rządu, ale stanowił wręcz jego część.

Po zmianie przepisów w 1935 r. akcja przeciwko kartelom gwałtownie nasiliła się. W grudniu tego roku Minister Przemysłu i Handlu rozwiązał aż 93 porozumienia kartelowe ${ }^{38}$. W następnych dwóch latach rozwiązano kilkadziesiąt dalszych umów kartelowych ${ }^{39}$. Wprowadzone zmiany legislacyjne miały wybitnie polityczne podłoże, wyposażając rząd w szybkie i skuteczne środki do realizacji przyjętych założeń gospodarczych.

Kolejnym krokiem na drodze do ścisłego podporządkowywania karteli nadzorowi państwa była nowa ustawa o porozumieniach kartelowych uchwa-

${ }^{33}$ Ibidem, s. 55.

${ }^{34}$ Dekret Prezydenta Rzeczypospolitej z dnia 27 listopada 1935 r. w sprawie zmiany ustawy z dnia 28 marca 1933 r. o kartelach, Dz. U. Nr 86, poz. 529.

35 Zgodnie $\mathrm{z}$ art. 14 ust. $2 \mathrm{w}$ nowym brzmieniu, sąd oddalając wniosek o uchylenie orzeczenia ministra zasądzał od strony, która wystąpiła $\mathrm{z}$ wnioskiem, opłaty sądowe w kwocie nieprzewyższającej 20000 zł oraz koszty postępowania.

36 „Rocznik Polityczny i Gospodarczy” 1939 (reprint wydany przez Polską Agencję Prasową), Warszawa 2003, s. 815 i 803.

${ }^{37}$ Ibidem, s. 815.

38 Z. Landau, op. cit., s. 83.

39 „Rocznik Polityczny i Gospodarczy” 1939, s. 803. 
lona $\mathrm{w}$ przededniu wojny ${ }^{40}$. Przewidywała ona rewolucyjne zmiany $\mathrm{w}$ systemie antymonopolowym - nie wystarczało, aby kartel nie zagrażał dobru publicznemu, musiał zostać zawiązany w celu użytecznym dla gospodarki narodowej, określonym wyraźnie w treści porozumienia kartelowego. Kartel powstawał dopiero z chwilą wpisu do rejestru - dotychczas deklaratywny charakter wpisu zamieniono na konstytutywny. W gestii Ministra Przemysłu i Handlu było więc nie tylko rozwiązanie kartelu, ale też uniemożliwienie jego powstania poprzez odmowę wpisu do rejestru. Orzeczenie takie miało zapadać, gdy porozumienie kartelowe nie wskazywało celów odpowiadającym interesom gospodarki narodowej lub środków ich urzeczywistnienia. Kartelom, z natury rzeczy dążącym do maksymalizacji zysków i ograniczenia konkurencji, chciano narzucić rolę narzędzia polityki gospodarczej rządu. Wejście w życie ustawy uniemożliwiła wojna ${ }^{41}$, prawdopodobnie jednak w wyżej wskazanym zakresie regulacja nie odniosłaby pożądanego skutku - w preambule umów kartelowych widniałyby podniosłe cele, a rzeczywiste motywy zawiązania kartelu ukryte byłyby między wierszami ${ }^{42}$. Ustawa skutecznie natomiast realizowała koncepcję ścisłego podporządkowania zrzeszeń kartelowych rządowi, dając mu instrumenty do wykonywania nadzoru i likwidacji niepożądanych podmiotów.

\section{SYSTEM OCHRONY KONKURENCJI PO II WOJNIE ŚWIATOWEJ}

Po zakończeniu II wojny światowej nie wprowadzono systemu ochrony konkurencji - pierwsza ustawa antymonopolowa została wydana dopiero na fali liberalizacji gospodarczej w $1987 \mathrm{r} .{ }^{43}$ Centralnym organem monopolowym - podobnie jak przed wojną - został członek rządu - Minister Finansów. Decyzja kończąca postępowanie antymonopolowe, z racji wydawania przez naczelny organ administracji państwowej, była ostateczna i nie przysługiwało od niej odwołanie ${ }^{44}$. Ustawa wprowadzała rozbudowany system sankcji zróżnicowanych w zależności od rodzaju naruszenia, charakteru jednostki oraz od tego, czy doszło do pierwszego, ponownego czy też wielokrotnego naruszenia

40 Ustawa z dnia 13 lipca 1939 r. o porozumieniach kartelowych, Dz. U. Nr 63, poz. 418.

${ }^{41}$ Ustawa miała wejść w życie z dniem 20 października 1939 r.

42 Por. cytat z H. Tannenbaum, Zaktamanie kartelowe, „Kurier Warszawski“ z 17 marca 1939 r., nr 17/ 1939, s. 14, przytoczony przez Z. Landau, op. cit., s. 84.

${ }^{43}$ Ustawa z dnia 28 stycznia 1987 r. o przeciwdziataniu praktykom monopolistycznym w gospodarce narodowej, Dz. U. Nr 3, poz. 18.

${ }^{44}$ A. Sopoćko, W. Modzelewski, J. Bielawny, Polityka antymonopolowa, Towarzystwo Naukowe Organizacji i Kierownictwa „Dom Organizatora”, Toruń 1989, s. 190. 
prawa $^{45}$. Należy podkreślić, iż postępowanie przed organem antymonopolowym mogło być wszczęte nie tylko z urzędu, ale także na wniosek m.in. jednostek gospodarczych, których interesom zagrażały praktyki monopolistyczne oraz organizacji społecznych, do których zadań statutowych należała ochrona konsumentów. Sądową kontrolę decyzji ministra powierzono Naczelnemu Sądowi Administracyjnemu. Wprowadzono więc administracyjny model ochrony konkurencji. Powierzenie funkcji organu antymonopolowego członkowi rządu było przedmiotem krytyki - jak wskazywano w piśmiennictwie, ewolucja organu antymonopolowego powinna zakończyć się utworzeniem niezależnego ciała orzekającego, które przejęłoby funkcje ministra w tym zakresie ${ }^{46}$.

Postulat utworzenia odrębnego od rządu organu zrealizowano po transformacji ustrojowej w 1990 r. powołując Urząd Antymonopolowy ${ }^{47}$. Nie korzystał on jednak z przymiotu niezależności - wyraźnie wskazano, iż podlega on Radzie Ministrów ${ }^{48}$. Prezesa i wiceprezesa Urzędu powoływał i odwoływał premier, a rząd nadawał Urzędowi statut. Pierwszy w wolnej Polsce organ ochrony konkurencji bezpośrednio podporządkowano rządowi.

Powołanie Urzędu Antymonopolowego stanowiło jeden $\mathrm{z}$ istotnych elementów pakietu reform wdrażanych w celu urzeczywistnienia wolnego rynku. Struktura gospodarki, odziedziczona po systemie centralnego planowania, charakteryzowała się bowiem wysokim poziomem monopolizacji, co mogło w istotny sposób ograniczyć powodzenie transformacji gospodarczej ${ }^{49}$. Podporządkowanie organu antymonopolowego rządowi w tym kluczowym okresie reform miało więc swoje uzasadnienie.

Od decyzji Urzędu Antymonopolowego przysługiwało odwołanie do Sądu Antymonopolowego ${ }^{50}$. Sąd ten nie był sądem specjalnym, lecz został utworzony jako nowy wydział Sądu Wojewódzkiego w Warszawie. Wprowadzono więc szczególny tryb zaskarżania decyzji administracyjnych w sprawach antymonopolowych. Ustawodawca zrezygnował $\mathrm{z}$ charakterystycznego dla postępowania administracyjnego $\mathrm{w}$ innych sprawach trybu odwołania do organu

${ }^{45}$ Ibidem, s. 145, 169-190.

46 Ibidem, s. 256.

47 Ustawa z dnia 24 lutego 1990 r. o przeciwdziataniu praktykom monopolistycznym, Dz. U. $\mathrm{Nr} 14$, poz. 88.

48 Ibidem, art. 17 ust. 1.

${ }^{49}$ Urząd Ochrony Konkurencji i Konsumentów, Historia Urzędu, http://uokik.gov.p1/historia_urzedu.php (27.02.2013).

${ }^{50}$ Orzecznictwo w sprawach antymonopolowych przekazano więc $\mathrm{z}$ sądu administracyjnego do powszechnego (na podstawie nowelizacji ustawy z dnia 20 czerwca 1985 r. Prawo o ustroju sqadów powszechnych, Dz. U. Nr 27, poz. 157 oraz rozporzadzenia Ministra Sprawiedliwości z dnia 13 kwietnia 1990 r. w sprawie utworzenia sqadu antymonopolowego, Dz. U. Nr 27, poz. 157). 
II instancji, a następnie do NSA, na rzecz bezpośredniej kontroli sprawowanej przez sąd powszechny ${ }^{51}$.

W 1996 r., w ramach ogólnej reformy administracji centralnej, zmieniono nazwę Urzędu Antymonopolowego na Urząd Ochrony Konkurencji i Konsumentów (UOKiK), którą nosi do dziśs ${ }^{52}$. Centralnym organem administracji rządowej stał się Prezes UOKiK, a nie jak dotychczas sam urząd ${ }^{53}$. Jednocześnie do kompetencji Prezesa Urzędu przekazano ochronę interesów konsumentów. Zakres jego zadań wielokrotnie poszerzano tak, że aktualnie pełni on wiele funkcji niezwiązanych bezpośrednio z działalnością antymonopolową ${ }^{54}$.

W 2000 r. podległość Prezesa UOKIK rządowi zastąpiono nadzorem premiera nad jego działalnością ${ }^{55}$. Nowelizacja ta miała na celu podkreślenie konieczności uniezależnienia Prezesa UOKiK od bieżącej polityki rzą$\mathrm{du}^{56}$. Nadal jednak premier zachowywał całkowitą swobodę w wyborze Prezesa UOKiK, który mógł być też w każdym momencie przez niego odwołany. W takiej sytuacji nie można było mówić o niezależnym od rządu organie antymonopolowym.

Istotne zmiany $\mathrm{w}$ tym zakresie przyniosła nowa ustawa antymonopolowa uchwalona pod koniec 2000 r. ${ }^{57}$ Od tej pory Prezes UOKiK wyłaniany był w drodze konkursu i powoływany przez premiera na 5-letnią kadencję. Jego odwołanie mogło nastąpić tylko $\mathrm{w}$ przypadkach ściśle wymienionych $\mathrm{w}$ usta$w_{i e}^{58}$. Wprowadzono więc podstawowe gwarancje niezależności organu: wymóg posiadania wysokich kwalifikacji zawodowych weryfikowanych w drodze

${ }^{51}$ C. Banasiński, Ewolucja ustawodawstwa antymonopolowego w Polsce, [w:] C. Banasiński (red.), Ochrona konkurencji i konsumentórw w Polsce i Unii Europejskiej (studia prawno-ekonomiczne), Urząd Ochrony Konkurencji i Konsumentów, Warszawa 2005, s. 13. W literaturze wskazuje się, iż decyzja została podjęta bez szerszej refleksji nad konsekwencjami przyjętych rozwiązań prawnych (por. M. Błachucki, Sądownictwo antymonopolowe w Polsce - Historia i ustrój, Urząd Ochrony Konkurencji i Konsumentów, Warszawa 2011, s. 9 i cytowana tam literatura).

${ }_{52}$ Ustawa z dnia 8 sierpnia 1996 r. o zmianie niektórych ustaw normujacych funkcjonowanie gospodarki i administracji publicznej, Dz. U. Nr 106, poz. 496. Zmiana nazwy miała na celu przede wszystkim uwypuklenie nowych zadań urzędu w zakresie ochrony konsumentów.

53 C. Banasiński, Erwolucja ustawodawstwa..., op. cit., s. 15.

${ }^{54}$ Por. art. 26 ustawy z dnia 15 grudnia 2000 r. o ochronie konkurencji i konsumentów, Dz. U., nr 122, poz. 1319. Zakres zadań Prezesa UOKiK istotnie poszerzył się także w związku z polską akcesją do Unii Europejskiej.

55 Ustawa z dnia 2 marca 2000 r. o zmianie ustawy o przeciwdziataniu praktykom monopolistycznym $i$ ochronie interesów konsumentów, Dz. U. Nr 31, poz. 381. Ustawa weszła w życie z dniem 6 maja $2000 \mathrm{r}$.

${ }_{56}$ C. Banasiński, Ewolucja ustawodawstwa..., op. cit., s. 16.

57 Ustawa z dnia 15 grudnia 2000 r. ..., op. cit., Dz. U. Nr 122, poz. 1319.

${ }^{58}$ Art. 24 ust. 5 ww. ustawy. 
konkursu ${ }^{59}$, kadencyjność, nieodwołalność przed upływem kadencji ${ }^{60}$. Nadzór nad działalnością Prezesa UOKiK sprawował nadal premier.

Te same standardy zachowano w kolejnej ustawie antymonopolowej z 2007 r. $^{61}$ Niestety, niespełna dwa miesiące po uchwaleniu ustawy przegłosowano jej zmianę upolityczniającą urząd Prezesa ${ }^{62}$. Nowelizacja, której projekt przedłożył Prezydent, przewidywała, że Prezes Urzędu będzie powoływany przez premiera spośród osób należących do państwowego zasobu kadrowego. Zasób ten miał skupiać ludzi z kwalifikacjami odpowiednimi do objęcia wyższych stanowisk w administracji ${ }^{63}$. Przede wszystkim jednak, niejako przy okazji, zlikwidowano kadencyjność Prezesa UOKiK - premier mógł go powołać i odwołać go w każdym czasie. Zmiana ta zakończyła krótki w polskiej historii okres niezależności organu antymonopolowego.

Niedługo później wybór Prezesa z państwowego zasobu kadrowego zastąpiono wyłanianiem w drodze otwartego i konkurencyjnego naboru ${ }^{64}$. W rzeczywistości jednak wybór Prezesa UOKiK nie następuje w drodze konkursu, a wybrany kandydat nie musi posiadać najlepszych kwalifikacji ${ }^{65}$. Utrzymano więc uzależnienie Prezesa UOKiK od rządu i polityczny charakter jego wyboru. Taki stan prawny obowiązuje do dziś.

\section{ZAKOŃCZENIE}

Jak wskazał W. Eucken, istnieje głęboka analogia pomiędzy ustrojem opartym na konkurencji a ideą rządów prawa ${ }^{66}$. Podobnie jak państwo prawa, ład oparty na konkurencji powinien tworzyć ramy, w których ograniczeniem sfery wolności jednostki jest zakres wolności innej jednostki. Dzięki temu możliwe jest osiągnięcie stanu równowagi pomiędzy podmiotami uczestniczącymi w grze rynkowej. „Sama chęć urzeczywistnienia tego pragnienia wystarcza

${ }^{59} \mathrm{~W}$ ustawie zawarto delegację dla Prezesa Rady Ministrów do wydania rozporządzenia określającego skład komisji konkursowej i wymogi wobec jej członków, kierując się koniecznością zapewnienia obiektywności wyboru Prezesa Urzędu (art. 24 ust. 3).

${ }^{60}$ Por. M. Błachucki, System postepowania..., op. cit., s. 85.

${ }^{61}$ Ustawa z dnia 16 lutego 2007 r. o ochronie konkurencji i konsumentów, Dz. U. Nr 50, poz. 331).

${ }^{62}$ Ustawa z dnia 13 kwietnia 2007 r. o zmianie ustawy o ochronie konkurencji i konsu-mentów oraz ustawy o państwowym zasobie kadrowym $i$ wysokich stanowiskach państwowych, Dz. U. Nr 99, poz. 660. Ustawa weszła w życie $\mathrm{z}$ dniem 20 czerwca $2013 \mathrm{r}$.

${ }^{63}$ Nowy sposób wyboru prezesa UOKiK, http://wiadomosci.gazeta.pl/wiadomosci/1,114873,4055743.html (28.02.2013).

${ }^{64}$ Ustawa z dnia 21 listopada 2008 r. o stużbie cywilnej, Dz. U. Nr 227, poz. 1505, art. 188.

${ }_{65}$ M. Błachucki, System postępowania..., op. cit., s. 90.

${ }^{66}$ W. Eucken, op. cit., s. 291. 
w równie małym stopniu, jak afirmacja państwa prawnego i zwykła wiara w jego nadejście wystarczają, by ono powstało. Należy zarówno zbudować dom, jak i narysować projekt" ${ }^{67}$.

Podobnie w polskim systemie ochrony konkurencji nie wystarcza zwykłe przeświadczenie o niezależności centralnego urzędu antymonopolowego. Bez realnych gwarancji tej niezależności urzeczywistnienie ustroju opartego na konkurencji pozostanie jedynie w sferze postulatów dalekich od realizacji.

Pomimo tych niedoskonałości systemowych działalność Prezesa UOKiK zasługuje na ogólnie dobrą ocenę, docenić bowiem należy jego rolę w ochronie konkurencji. Można jednak przypuszczać, że całkowita niezależność Prezesa Urzędu doprowadziłaby do jeszcze lepszych rezultatów. Tylko pełna niezależność zabezpieczyłaby interesy ogółu i nie pozostawiłaby miejsca dla politycznych ingerencji kolejnych ekip rządowych. Pozostawienie tak ważkiej kwestii w nurcie bieżącej polityki stanowi zbyt duże ryzyko i - w świetle teorii i praktyki konkurencji - nie ma żadnego uzasadnienia.

W okresie II Rzeczypospolitej, po przekazaniu całości kompetencji w sprawach kartelowych ministrowi, organ antymonopolowy realizował bieżącą politykę rządu. Szkoda, że współcześnie polski ustawodawca nie wykorzystał doświadczeń międzywojennych i w 2007 r. przerwał proces tworzenia politycznie neutralnego urzędu, piastowanego przez specjalistów wyłanianych w drodze konkursu i wyposażonych w ustawowe gwarancje niezależności ${ }^{68}$. Odsunięcie organu ochrony konkurencji od linii aktualnej polityki rządu jest bowiem standardem ustawodawstwa antymonopolowego w większości pozostałych państw europejskich.

\section{BIBLIOGRAFIA}

Banasiński C., Ewolucja ustawodawstwa antymonopolowego w Polsce, [w:] C. Banasiński (red.), Ochrona konkurencji i konsumentów w Polsce i Unii Europejskiej (studia prawno-ekonomiczne), Urząd Ochrony Konkurencji i Konsumentów, Warszawa 2005.

Błachucki M., Saqdownictwo antymonopolowe w Polsce - Historia i ustrój, Urzq̨d Ochrony Konkurencji i Konsumentów, Warszawa 2011.

${ }^{67}$ Ibidem.

${ }_{68}$ M. Stefaniuk, Ewolucja ustroju polskiej administracji publicznej w dziedzinie ochrony konkurencji w latach 1998-2008, [w:] J. Parchomiuk, B. Ulijasz, E. Kruk (red.), Dziesięć lat reformy ustrojowej administracji publicznej w Polsce. Ogólnopolska konferencja naukowa, Łańcut, 12-14 czerwca 2008, Oficyna a Wolters Kluwer Business, Warszawa 2009, s. 263. 
Błachucki M., System postepowania antymonopolowego w sprawach kontroli koncentracji przedsiębiorców, UOKiK, Warszawa 2012.

Eucken W., Podstawy polityki gospodarczej, Wydawnictwo Poznańskie, Poznań 2005.

Grabski W., O wtasnych sitach. Zbiór artykutów na czasie, Gebethner i Wolff, Warszawa-Kraków-Lublin-Łódź-Paryż-Wilno-Zakopane 1926.

Grossekettler H., Franz Böhm (1895-1977), [w:] The Elgar Companion to Law and Economics, J.G. Backhaus (red.), Edward Elgar, Cheltenham, Northampton 2005.

Krajewski M., Historia gospodarcza Polski do 1989 roku. Zarys problematyki, Wyższa Szkoła Humanistyczno-Ekonomiczna, Włocławek 2000.

L.P., Kartele a kryzys, „Kurjer Lubelski” z 5 lutego 1932 r., r. X, nr 36/1932.

Landau Z., Rozwiazanie kartelu cementowego w Polsce w 1933 r., „Studia Historyczne", z. 1/1972.

Landau Z., Rozwój ustawodawstwa kartelowego w Polsce międzywojennej na tle polityki kartelowej rządu, „Kwartalnik Historyczny”, z. 1/1972, s. 69-86.

Łapa M., Przymusowa kartelizacja przemystu II Rzeczypospolitej w latach 1925-33, „Acta Universitatis Lodziensis. Folie Historiae", nr 60/1997.

Nowy sposób wyboru prezesa UOKiK, http://wiadomosci.gazeta.pl/wiadomosci/1,114873,4055743.html (28.02.2013).

Podolska A., Polska ustawa kartelowa w II Rzeczypospolitej, „Czasopismo Prawno-Historyczne”, t. LII, z. 1-2/2000.

Podolska-Meducka A., Polskie ustawodawstwo kartelowe w latach 1918-1939, Wydawnictwo Sejmowe, Warszawa 2003.

Podolska-Meducka A., Projekty ustawy kartelowej w Polsce międzywojennej, „Czasopismo Prawno-Historyczne", t. LIV, z. 2/2002.

Podolska-Meducka A., Są Kartelowy w Polsce i jego orzecznictwo w latach 1933-1935, „Czasopismo Prawno-Historyczne”, t. LIII, z. 2/2001.

Rocznik Polityczny i Gospodarczy 1939 (reprint wydany przez Polską Agencję Prasową), Warszawa 2003.

Sopoćko A., Modzelewski W., Bielawny J., Polityka antymonopolowa, Towarzystwo Naukowe Organizacji i Kierownictwa „Dom Organizatora”, Torun 1989.

Stefaniuk M., Ewolucja ustroju polskiej administracji publicznej w dziedzinie ochrony konkurencji w latach 1998-2008, [w:] J. Parchomiuk, B. Ulijasz, E. Kruk (red.), Dziesięć lat reformy ustrojowej administracji publicznej w Polsce. Ogólnopolska konferencja naukowa, Łańcut, 12-14 czerwca 2008, Oficyna a Wolters Kluwer Business, Warszawa 2009.

Tannenbaum H., Zaktamanie kartelowe, „Kurier Warszawski“ z 17 marca 1939 r., nr $17 / 1939$.

Urząd Ochrony Konkurencji i Konsumentów, Historia Urzędu, http://uokik.gov.p1/historia_urzedu.php (27.02.2013).

Ustawa z dnia 2 lipca 1920 r. o zwalczaniu lichwy wojennej, Dz. U. Nr 67, poz. 449.

Rozporządzenie Prezydenta Rzeczypospolitej z dnia 31 sierpnia 1926 r. o zabezpieczeniu podaży przedmiotów powszedniego użytku, Dz. U. Nr 91, poz. 527.

Ustawa z 28 marca 1933 r. o kartelach, Dz. U. Nr 31, poz. 270. 
Dekret Prezydenta Rzeczypospolitej z dnia 27 listopada 1935 r. w sprawie zmiany ustawy z dnia 28 marca 1933 r. o kartelach, Dz. U. Nr 86, poz. 529.

Ustawa z dnia 13 lipca 1939 r. o porozumieniach kartelowych, Dz. U. Nr 63, poz. 418.

Ustawa z dnia 20 czerwca 1985 r. Prawo o ustroju sadów powszechnych, Dz. U. Nr 27, poz. 157.

Ustawa z dnia 28 stycznia 1987 r. o przeciwdziataniu praktykom monopolistycznym w gospodarce narodowej, Dz. U. Nr 3, poz. 18.

Ustawa z dnia 24 lutego 1990 r. o przeciwdziataniu praktykom monopolistycznym, Dz. U., nr 14, poz. 88.

Rozporzadzenie Ministra Sprawiedliwości z dnia 13 kwietnia 1990 r. w sprawie utworzenia sqdu antymonopolowego, Dz. U. Nr 27, poz. 157.

Ustawa z dnia 8 sierpnia 1996 r. o zmianie niektórych ustaw normujacych funkcjonowanie gospodarki i administracji publicznej, Dz. U. Nr 106, poz. 496.

Konstytucja Rzeczypospolitej Polskiej z dnia 2 kwietnia 1997 r., Dz. U. Nr 78, poz. 483.

Ustawa z dnia 15 grudnia 2000 r. o ochronie konkurencji i konsumentów, Dz. U. Nr 122, poz. 1319.

Ustawa z dnia 2 marca 2000 r. o zmianie ustawy o przeciwdziataniu praktykom monopolistycznym i ochronie interesów konsumentów, Dz. U. Nr 31, poz. 381.

Ustawa z dnia 16 lutego 2007 r. o ochronie konkurencji i konsumentórw, Dz. U. Nr 50, poz. 331.

Ustawa z dnia 13 kwietnia 2007 r. o zmianie ustawy o ochronie konkurencji i konsu-mentów oraz ustawy o państwowym zasobie kadrowym $i$ wysokich stanowiskach państwowych, Dz. U. Nr 99, poz. 660.

Ustawa z dnia 21 listopada 2008 r. o stużbie cywilnej, Dz. U. Nr 227, poz. 1505. 
